\title{
Transcriptional analysis of genes involved in nodulation in soybean roots inoculated with Bradyrhizobium japonicum strain CPAC 15
}

\author{
Gesiele Almeida Barros de Carvalho 1,2, Jesiane Stefânia Silva Batista ${ }^{1}$, Francismar Corrêa Marcelino-Guimarães ${ }^{1}$, \\ Leandro Costa do Nascimento ${ }^{3}$ and Mariangela Hungria ${ }^{1 *}$
}

\begin{abstract}
Background: Biological nitrogen fixation in root nodules is a process of great importance to crops of soybean [Glycine max (L.) Merr.], as it may provide the bulk of the plant's needs for nitrogen. Legume nodulation involves several complex steps and, although studied for many decades, much remains to be understood.

Results: This research aimed at analyzing the global expression of genes in soybean roots of a Brazilian cultivar (Conquista) inoculated with Bradyrhizobium japonicum CPAC 15, a strain broadly used in commercial inoculants in Brazil. To achieve this, we used the suppressive subtractive hybridization (SSH) technique combined with Illumina sequencing. The subtractive library (non-inoculated $x$ inoculated) of soybean roots resulted in 3,210 differentially expressed transcripts at 10 days after inoculation were studied. The data were grouped according to the ontologies of the molecular functions and biological processes. Several classes of genes were confirmed as related to $\mathrm{N}_{2}$ fixation and others were reported for the first time.

Conclusions: During nodule formation, a higher percentage of genes were related to primary metabolism, cell-wall modifications and the antioxidant defense system. Putative symbiotic functions were attributed to some of these genes for the first time.
\end{abstract}

Keywords: Subtractive library, Differential expression of genes, Nodulation

\section{Background}

Soybean (Glycine max (L.) Merr.) has significant agronomic and nutritional relevance because of the high concentrations of protein and oil in its grains. Concomitant with the high protein content, the legume shows a strong demand for nitrogen (N) for optimal development and grain productivity [1]. Although atmospheric $\mathrm{N}_{2}$ is abundant, no eukaryotic organism is able to directly assimilate it, due to the strong triple bond linking the atoms $[2,3]$. However, when growing in $\mathrm{N}$ depleted soils, much of soybean's need for $\mathrm{N}$ can be obtained via biological nitrogen fixation (BNF) in root nodules, through the symbiotic association with bacteria, collectively called rhizobia, belonging mainly to the species Bradyrhizobium japonicum and Bradyrhizobium elkanii $[4,5]$.

\footnotetext{
* Correspondence: mariangela.hungria@embrapa.br

${ }^{1}$ Empresa Brasileira de Pesquisa Agropecuária, CNPSo, PO Box 231, Londrina, Paraná 86001-970, Brazil

Full list of author information is available at the end of the article
}

In Brazil, estimates indicate that the value of BNF by soybean root nodules is equivalent to $\mathrm{U} \$ 7$ billion/year; furthermore, BNF is an environmentally beneficial process, in comparison to the use of synthetic $\mathrm{N}$ fertilizers $[4,5]$.

The establishment of the symbiosis starts with molecular interactions between the rhizobia and the host plant, involving a succession of complex processes that lead to profound changes in both symbionts $[3,6]$. The plant releases molecular signals, in particular flavonoid compounds, that are primary inducers of rhizobial nodulation genes. The induction of this class of genes leads to the biosynthesis of Nod factors, rhizobial signals that trigger specific responses in the root hairs of the host plant; plant cells perceive the presence of Nod factorsand of the rhizobia-through cell-surface receptors on the roots [7-10]. Many molecular events are triggered in a coordinated manner, leading to morphological and

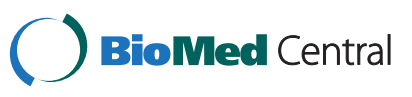


physiological changes in the host plant, necessary for a successful symbiosis [3].

Given the complexity of the symbiosis, studies of transcriptional profiles during nodulation are important to gain greater understanding of the nodulation process. Studies conducted with soybean, e.g. Brechenmacher et al. [2], evaluated gene-expression profiles in roots inoculated with B. japonicum (USDA 110), and elucidated reduced plant defenses. Furthermore, a complex regulatory mechanism in the plant was detected, enabling it to adapt to changes in its nutritional status. Another study of the transcriptome of soybean roots inoculated with strain USDA 110 showed rapid changes in gene expression in response to inoculation, with the pattern modified in accordance with the various stages of nodule development and function [11].

Brazil is the second most prolific producer of soybean worldwide, and probably the country where BNF has been exploited most successfully $[4,5]$. However, no investigation of transcriptomics with Brazilian strains and cultivars have been reported. This study aimed at analyzing the global expression of genes in soybean roots of cultivar Conquista inoculated with B. japonicum strain CPAC 15 (=SEMIA 5079), both broadly used in Brazil, through the suppressive subtractive hybridization (SSH) technique [12] combined with sequencing Illumina analysis.

\section{Results and discussion}

The SSH library of the Brazilian cultivar Conquista, at 10 days after inoculation (DAI) with $B$. japonicum strain CPAC 15, which is broadly used in commercial inoculants in Brazil, resulted in 4,621,072 reads.

Among the 3,776 sequences identified as up-regulated, 3,210 were automatically recorded by the AutoFACT tool and grouped into functional categories (GO), according to the ontologies of molecular function $(1,764$ sequences) and biological process (1,728 sequences), using Blast2GO software [13]. The remaining 566 sequences presented no similarity with a known protein of the database.

Concerning molecular function (Figure 1A), the categories including more reads were those of ion binding,

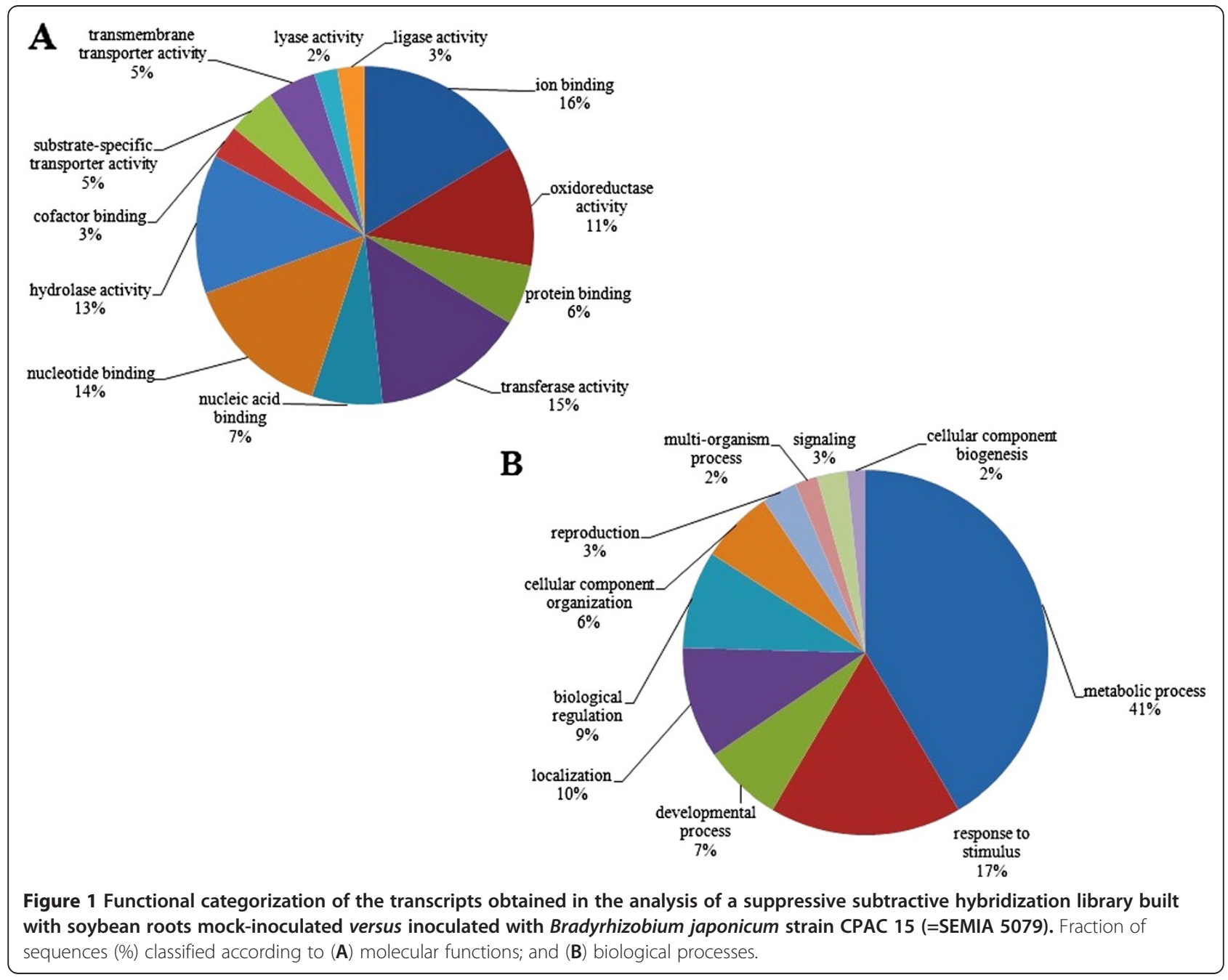


followed by transferase activity, nucleotide binding, hydrolase activity and oxidoreductase activity, demonstrating intense metabolic activity occurring during the nodulation process. Figure $1 \mathrm{~B}$ highlights the biological processes triggered in the host plant, at $10 \mathrm{DAI}$ with rhizobia, where the most representative category was of the metabolic process, followed by response to stimulus. Table 1 displays a detailed description of the main biological processes, triggered in the soybean roots by the presence of the nitrogen-fixing bacteria. In general, our results are consistent with those obtained with other legumes evaluated during nodulation, for example, Medicago truncatula, in which many physiological processes were increased by the presence of rhizobia, leading to the induction of genes involved in signaling, transcriptional regulation, intracellular calcium oscillations, oxidative explosion, cell proliferation and alterations in the cytoskeleton, all necessary for nodule development and function [14-16].

Furthermore, studies with Lotus japonicus indicate that genes involved in across-membrane transport, hormone metabolism, cell-wall modification and signal transduction were also induced by the presence of the bacteria $[17,18]$.

Moreover, we also identified in our library nodulin-21 [19], nodulin-22 [20], nodulin-26 [21], nodulin-36 [22], among others, which are recognized as induced genes in the tested condition, giving further confidence in $\mathrm{SSH}$ data.

For a more focused discussion of our results, categories were selected based on the high level of gene expression (RPKM, reads per kilobase of exon per million mapped reads), in comparison to the RPKM values of genes validated by RT-qPCR (Additional file 1: Table S1). Therefore, we assume that other genes with greater values of RPKM are also up-regulated during soybean nodulation.

\section{Metabolic process}

Previous studies of the effects of inoculation of soybean with B. japonicum, at various stages of nodulation, ranging from hours (12, 24 and 48), days (4, 8 and 16) and weeks (2, 5 and 10) [2,11,23] after inoculation have reported profound changes in plant metabolism, that varied with the growth stage analyzed [24]. Thus, our study is in accordance with Hayashi et al. [25] because the Nod factors perception cause metabolic changes, and here we can observed that the metabolic pathways most active in the presence of rhizobia were glycolysis and the Krebs cycle (Additional file 2: Figures S1 and S2). Indeed, for the development and functioning of nodules, it is necessary to allocate plant sources of $\mathrm{C}$ to the new organs [26,27]. Similarly, genes involved in the breakdown of sucrose, glycolysis and synthesis of amino acids were found to be differentially expressed in $L$. japonicus, consistent with these processes being accelerated during nodulation [28]. The glycolytic pathway and Krebs cycle are closely linked, representing the main ways of acquiring energy. Consistent with the $\mathrm{N}_{2}$-fixing symbiosis being an energy-demanding process [26,29,30], the expression of genes related to both pathways increased. Additional file 1: Table S2 presents the identified genes related to energetic pathways; of these, Glyma14g36850.1 (fructose-biphosphate aldolase) had the highest level of expression based on its RPKM value. This enzyme participates in the production of dicarboxylic acids for rhizobial and carbon skeletons for the assimilation of $\mathrm{N}$ by the plant [14]. According to Brechenmacher et al. [2], this induction effect occurs from the eighth day after inoculation.

Among the metabolic processes, nodulation also changes the redox state of root cells, and a major metabolic pathway activated by CPAC 15 was the synthesis of glutathione (Additional file 2: Figure S3), which is protective against reactive oxygen species (ROS) [31]. The levels of expression of the genes for glutathione peroxidase, gammaglutamyl transferase and glutathione S-transferase were higher than for the other genes encoding enzymes in this pathway (Table 2).

As shown by Chang et al. [32], changes in redox state are observed at various stages of nodulation. They occurred during early symbiotic interactions in Medicago sativa [33] and Phaseolus vulgaris [34]. Transcripts present in the subtractive library, which participate of antioxidant defense system, are shown in Table 2. In Medicago truncatula, inhibition of the synthesis of glutathione resulted in fewer nodules on inoculated roots, showing the critical role of glutathione in nodule morphogenesis $[31,35]$.

\section{Signaling}

Signal-transduction genes are important at the various stages of the symbiotic interaction, as they lead to the coordinated development of epidermal and cortical cells needed to permit rhizobial penetration and nodule initiation $[8,36]$. It is known that the processes of recognition and signaling triggered by the rhizobia activate genes related to nodulation; some of them have been characterized in soybean, such a receptor kinases NARK (nodule auto regulation receptor kinase) [37] and NORK (nodulation receptor kinase) [38], protein kinase type LRR (leucine rich repeat) encoded, respectively, by genes Glyma12g04390 and Glyma09g33510. Libault et al. [11] identified other genes related to the LRR proteins that are differentially regulated during nodulation.

Among the genes with high expression level identified in our library, two encoded LRRs (Table 3), highlighting Glyma16g29220.1, with the highest level of expression (based on RPKM values) among all genes of the SSH library. Therefore, this gene represents a novelty that may 
Table 1 Classification of biological processes triggered in soybean roots (cv. Conquista) in response to inoculation with strain CPAC 15 of B. japonicum

\begin{tabular}{|c|c|c|}
\hline ID GO & Description & $\mathrm{N}^{\circ}$ Seq. \\
\hline GO:0008150 & Biological process & 1,728 \\
\hline GO:0008152 & I- Metabolic process & 1,290 \\
\hline GO:0044237 & Cellular metabolic process & 964 \\
\hline GO:0044238 & Primary metabolic process & 756 \\
\hline GO:0019748 & Secondary metabolic process & 62 \\
\hline GO:0006807 & Nitrogen compound metabolic process & 269 \\
\hline GO:0009058 & Biosynthetic process & 373 \\
\hline GO:0009056 & Catabolic process & 195 \\
\hline GO:0044281 & Small molecule metabolic process & 324 \\
\hline GO:0043170 & I.a- Macromolecule metabolic process & 625 \\
\hline GO:0019538 & Protein metabolic process & 337 \\
\hline GO:0010467 & Gene expression & 69 \\
\hline GO:0050896 & II- Response to stimulus & 529 \\
\hline GO:0070887 & Response to chemical stimulus & 246 \\
\hline GO:0009628 & Response to abiotic stimulus & 162 \\
\hline GO:0009607 & Response to biotic stimulus & 56 \\
\hline GO:0006950 & II.a- Response to stress & 289 \\
\hline GO:0006952 & Defense response & 68 \\
\hline GO:0009719 & II.b- Response to endogenous stimulus & 113 \\
\hline GO:0009725 & Response to hormone stimulus & 106 \\
\hline GO:0032502 & III- Developmental process & 218 \\
\hline GO:0007275 & Multicellular organismal development & 124 \\
\hline GO:0048856 & III.a- Anatomical structure development & 114 \\
\hline GO:0048513 & Organ development & 73 \\
\hline GO:0051179 & IV- Localization & 308 \\
\hline GO:0051641 & Cellular localization & 56 \\
\hline GO:0033036 & Macromolecule localization & 60 \\
\hline GO:0051234 & IV.a- Establishment of localization & 306 \\
\hline GO:0006810 & Transport & 265 \\
\hline GO:0065007 & V- Biological regulation & 269 \\
\hline GO:0050789 & Regulation of biological process & 208 \\
\hline GO:0065008 & Regulation of biological quality & 80 \\
\hline GO:0071840 & VI- Cellular component organization or biogenesis & 203 \\
\hline GO:0071841 & Cellular component organization or biogenesis at cellular level & 136 \\
\hline GO:0016043 & Cellular component organization & 171 \\
\hline GO:0044085 & VII- Cellular component biogenesis & 51 \\
\hline GO:0000003 & VIII- Reproduction & 97 \\
\hline GO:0051704 & IX- Multi-organism process & 62 \\
\hline GO:0051707 & Response to other organism & 51 \\
\hline GO:0023052 & X- Signaling & 82 \\
\hline GO:0007165 & Signal transduction & 82 \\
\hline
\end{tabular}


Table 2 Genes that encode the soybean enzymes that participate in the metabolism of glutathione in the presence of B. japonicum strain CPAC 15

\begin{tabular}{|c|c|c|c|c|}
\hline EC number & Description & Gene & RPKM $^{a}$ & $\mathrm{~N}^{\circ}$ reads \\
\hline 1.1 .1 .42 & isocitrate dehydrogenase & Glyma14g39160.3 & 525.736 & 1,323 \\
\hline 1.1.1.44 & 6-phosphogluconic dehydrogenase & Glyma08g28230.1 & 366.492 & 616 \\
\hline 1.1.1.49 & glucose-6-phosphate dehydrogenase & Glyma19g24250.1 & 393.621 & 477 \\
\hline 1.11.1.9 & glutathione peroxidase & Glyma05g37900.3 & $3,425.42$ & 2,444 \\
\hline 1.8.1.7 & glutathione reductase & Glyma16g27210.1 & 590.971 & 658 \\
\hline 2.3.2.2 & gamma-glutamyltransferase & Glyma11g35950.1 & $1,631.78$ & 1,058 \\
\hline \multirow[t]{6}{*}{ 2.5.1.18 } & glutathione S-transferase & Glyma01g04690.1 & 1,392.19 & 344 \\
\hline & & Glyma06g20730.1 & $1,102.13$ & 1,774 \\
\hline & & Glyma07g16910.1 & 806.678 & 1,954 \\
\hline & & Glyma02g02860.1 & $1,013.09$ & 1,019 \\
\hline & & Glyma08g41960.1 & 693.606 & 1,347 \\
\hline & & Glyma12g28670.2 & 583.947 & 985 \\
\hline 6.3.2.2 & gamma-glutamylcysteine synthetase & Glyma05g37850.3 & 326.118 & 410 \\
\hline 6.3.2.3 & glutathione synthase & Glyma19g42600.1 & 363.132 & 148 \\
\hline
\end{tabular}

${ }^{a}$ Reads per kilobase of exon per million mapped reads.

b Identified in proteomics analysis.

be an important receptor. Besides soybean, LRRs have also been identified in the roots of Lotus japonicus [39], Medicago truncatula and Sesbania rostrata inoculated with their specific symbionts [40].

Also noteworthy are genes encoding calmodulins (Table 3), important proteins that participate in the transduction of signals triggered by the interaction of Nod factors to specific receptors on the surface of the root and, thus, allowing the expression of nodulins [41]. The most common calmodulin genes identified in the nodulation of soybean are Glyma15g35070.1 and Glyma08g24360.1 [42], and here three other genes were detected (encoding Glyma05g13900.1, Glyma13g03910.1, Glyma20g10820.1), whose participation in nodulation had not been emphasized.

\section{Response to stimulus}

The category that combined the second largest number of transcripts was that of response to stimulus, which includes genes related to abiotic and biotic factors, including stress and defense responses and reactions to endogenous stimuli. These genes are involved in morphological, biochemical and physiological changes stimulated by inoculation with B. japonicum. Among the identified genes in this category we emphasize the calreticulin, protein PDR and glycoside hydrolases 19 (Table 3).

The calreticulins have great functional diversity; they participate in protein folding (chaperones), in the homeostasis of intracellular $\mathrm{Ca}^{2+}$ and signaling, and are also crucial for the growth and development of plants. Moreover, they are potent regulators of the plant in response to various stresses, including the activation of mechanisms of resistance to infections by pathogens [43-45]. These proteins have been broadly studied in animals, but their characterization in plant models remains limited [44]. Among the identified genes corresponding to calreticulins, Glyma20g23080.1 showed a high level of expression. Interestingly, no studies of the activities of these proteins during the nodulation have been reported.

Another gene detected in our study was related to a PDR-like-ABC transporter-family protein, involved in the responses to biotic and abiotic stresses in plants and fungi [46]. These proteins have been identified as transporters involved in the secretion of genistein in soybean roots in response to B. japonicum [47], thus with an important role in nodulation.

Genes encoding glycoside hydrolases-19 were also detected. They are also known as chitinases and, among other functions in the symbiosis, it is believed that they participate in the perception and degradation of Nod factors $[48,49]$. Xie et al. [50] showed an increase in activity of chitinase in the presence of Nod factors of rhizobia in soybean roots, suggesting that these enzymes can regulate the perception of Nod factors during nodulation.

\section{Transport}

Genes related to transport accounted for about $10 \%$ of differentially expressed genes; Table 3 displays the genes with the highest expression levels. This category was also expressed in the nodulation of M. truncatula [51] and includes, among others, genes encoding membrane-transport proteins. Aquaporins, membrane proteins responsible for 
Table 3 Genes selected, based on RPKM, from some biological processes induced in soybean roots inoculated with strain CPAC 15 of B. japonicum

\begin{tabular}{|c|c|c|c|c|}
\hline Biological process & Genes & Description & RPKM $^{a}$ & $\mathrm{~N}^{\circ}$ reads \\
\hline \multirow[t]{5}{*}{ Signaling } & Glyma16g29220.1 & LRR (Leucine rich repeat) & 210,781 & 158,479 \\
\hline & Glyma03g32700.2 & LRR (Leucine rich repeat) & $1,943.56$ & 1,149 \\
\hline & Glyma13g03910.1 & Calmodulin & $2,424.67$ & 1,940 \\
\hline & Glyma05g13900.1 & Calmodulin & 1,743 & 2,510 \\
\hline & Glyma20g10820.1 & Calmodulin & $1,470.5$ & 2,522 \\
\hline \multirow[t]{4}{*}{ Response to stimulus } & Glyma20g23080.1 & Calreticulin & $1,823.09$ & 5,531 \\
\hline & Glyma15g02220.1 & PDR (Pleiotropic drug resistance) & $1,735.93$ & 384 \\
\hline & Glyma08g29090.1 & Glycoside hydrolase 19 & $1,177.12$ & 1,319 \\
\hline & Glyma18g51980.1 & Glycoside hydrolase 19 & $1,027.26$ & 1,122 \\
\hline \multirow[t]{16}{*}{ Transport } & Glyma20g32000.1 & Aquaporin & $1,377.3$ & 3,533 \\
\hline & Glyma10g35520.2 & Aquaporin & $1,613.69$ & 3,245 \\
\hline & Glyma14g06680.5 & Aquaporin & 2,989.98 & 9,195 \\
\hline & Glyma12g29510.2 & Aquaporin & $1,744.05$ & 4,347 \\
\hline & Glyma12g08040.1 & Aquaporin & $5,022.48$ & 5,497 \\
\hline & Glyma05g32620.1 & $A B C$ transport & $1,834.5$ & 531 \\
\hline & Glyma08g00280.1 & $A B C$ transport & $1,053.41$ & 949 \\
\hline & Glyma08g28190.1 & Amino acid transporter & $1,734.53$ & 4,473 \\
\hline & Glyma18g51220.1 & Amino acid transporter & $2,511.83$ & 5,376 \\
\hline & Glyma20g33000.1 & Amino acid transporter & $1,273.41$ & 1,325 \\
\hline & Glyma10g32750.1 & Oligopeptide transporter & $2,462.59$ & 5,684 \\
\hline & Glyma19g45260.1 & Potassium transporter & $6,052.79$ & 4,615 \\
\hline & & Potassium transporter & $1,865.16$ & 1,468 \\
\hline & & Potassium transporter & $1,636.9$ & 2,268 \\
\hline & & Potassium transporter & $2,088.8$ & 3,890 \\
\hline & Glyma03g31310.1 & Sulfate transporter & $1,421.28$ & 1,314 \\
\hline
\end{tabular}

${ }^{a}$ Reads per kilobase of exon per million mapped reads.

transport, especially of water, are expressed [52-54]. The soybean genes encoding aquaporins most commonly found on nodulation are Nodulin-26 (Glyma08g12650, Glyma$19 \mathrm{~g} 22210)$ found in the symbiosome [11,42]. Other genes encoding aquaporins were identified in our study (Table 3). During nodulation in Medicago truncatula, the aquaporins were the most expressed membrane proteins from early to relatively late stages of nodulation [14], emphasizing their importance during nodule organogenesis.

Other transporters are important for the acquisition of nutrients by root cells and the symbiosome [55]. Expression was detected of genes related to $\mathrm{ABC}$ transport, amino acid transport, and oligopeptide, potassium and sulfate transport (Table 3).

\section{Cell-wall modification}

Given the need for structural modification of the root during infection by rhizobia, several genes are involved in plant cell-wall penetration and cytoskeletal reorganization. Some genes involved in cell-wall modification encode enzymes involved in carbohydrate metabolism (Additional file 2: Figure S4). This is particularly important in nodulation, because the transcripts that encode enzymes (Table 4) active in this pathway may be acting specifically on the reorganization of the root and the formation of nodular structure.

A study by Kaewsuralikhit et al. [56], of soybean at 12 DAI, showed elevated expression of pectinesterase, one of the enzymes responsible for cell-wall degradation during the formation of nodules, which also occurs in Sesbania rostrata [57]. In Medicago truncatula, a pectinesterase was up-regulated and cellulase was induced on the third and fourth days post-inoculation [14]. And in the present study, we also identified the gene that encode pectinesterase $10 \mathrm{DAI}$, confirming that this gene is induced only some days post-inoculation, because in the early hours, the pectinesterase gene showed as downregulated [25].

Another important enzyme with a high level of expression in this study was sucrose synthase (Nodulin-100), 
Table 4 Genes encoding soybean enzymes active involved in carbohydrate metabolism

\begin{tabular}{|c|c|c|c|c|}
\hline EC number & Description & Gene & RPKM $^{\mathrm{a}}$ & $\mathrm{N}^{\circ}$ reads \\
\hline 1.1 .1 .22 & UDP-glucose 6-dehydrogenase & Glyma01g06970.1 & $1,118.45$ & 2,934 \\
\hline 2.4.1.12 & cellulose synthase & Glyma05g32100.1 & $1,225.43$ & 1,688 \\
\hline 2.4.1.13 & sucrose synthase & Glyma15g20180.3 & $1,552.25$ & 5,024 \\
\hline 2.4.1.25 & 4-alpha-glucanotransferase & Glyma03g27600.1 & 160.692 & 105 \\
\hline 2.4.1.34 & callose synthetase & Glyma06g44770.1 & 441.939 & 201 \\
\hline 2.7.1.1 & Hexokinase & Glyma11g01820.1 & 118.426 & 34 \\
\hline 3.1.1.11 & pectinesterase & Glyma03g03460.1 & $2,433.21$ & 2,497 \\
\hline 3.2.1.15 & polygalacturonase & Glyma05g37490.1 & 761.534 & 1,405 \\
\hline 3.2.1.2 & beta-amylase & Glyma06g45700.1 & 189.028 & 391 \\
\hline 3.2.1.26 & invertase & Glyma20g31730.1 & 677.598 & 1,994 \\
\hline 3.2.1.39 & glucan endo-1,3-beta-D-glucosidase & Glyma03g28850.1 & $2,612.62$ & 6,736 \\
\hline 3.2.1.4 & cellulase & Glyma05g36930.1 & 608.64 & 417 \\
\hline 4.1.1.35 & UDP-glucuronate decarboxylase & Glyma12g06980.3 & 193.024 & 268 \\
\hline 5.4.2.2 & phosphoglucomutase & Glyma05g34790.1 & $1,159.25$ & 2,329 \\
\hline
\end{tabular}

${ }^{a}$ Reads per kilobase of exon per million mapped reads.

b Identified in proteomics analysis.

which, among other known functions in nodulation, contributes significantly to development of cell wall [58].

\section{SSH validation by RT-qPCR and proteomics}

Two genes, represented by Glyma16g06940 and Glyma 18g05710, were chosen for SSH validation by RT-qPCR. We took the genes that showed RPKM values of 460.98 and 397.18 respectively, in order to verify the sensitivity and quality of the subtraction. Expression levels of both genes were up-regulated at the same time, 10 DAI (Additional file 1: Table S1).

Proteomics was used as a supplemental functional analysis, in view to validate the transcriptional data. In parallel with the RNA extraction, we also made the protein extraction of both conditions (inoculated and non-inoculated). Two-dimensional gel electrophoresis profiles of the two conditions were compared with each other. Representative spots, which showed a significant higher volume in the inoculated condition, were selected and identified by mass spectrometry.

Two spots were successfully identified and one of the selected spots didn't fit into the statistical parameters of identification. These two proteins identified were also found in the subtractive library data, which represents a functional confirmation of the transcriptomic analysis. Two of them were only detected in the inoculated condition: a putative glutathione-S-transferase (Glyma12g28670.2). The other identified protein was a sucrose synthase (Glyma15g20180.3), which had a 1.47 fold change in relation to the non-inoculated condition (Additional file 2: Figure S5). It is also worth mentioning that both spots identified correspond to the same Glyma IDs identified by the RNAseq analysis.

\section{Conclusions}

By using the SSH technique, it was possible to identify the main biological processes triggered in the Brazilian soybean cultivar Conquista after inoculation with the commercial strain CPAC 15 of B. japonicum. Among the main processes, we may highlight the metabolic pathways of primary metabolism, cell-wall modification and antioxidant-defense systems. Putative functions for some of these genes were assigned for the first time in the Bradyrhizobium-soybean symbiosis.

The analysis of transcriptional profiles of soybean in the presence of B. japonicum is essential to understand the symbiosis. Some transcripts have been previously described in nodulated soybean; however, novel genes were firstly described and could be related to the Brazilian germoplasm (plant genotype and bacterium), both studied by this standpoint for the first time.

\section{Methods}

\section{Plant material}

Soybean seeds of cultivar Conquista MG/BR46 were surface sterilized [59] and germinated on absorbent paper moistened with sterile distilled water, at $22 \pm 2^{\circ} \mathrm{C}$ (in the dark) for three days, and seedlings were transferred to sterile plastic bags containing $200 \mathrm{~mL}$ of $\mathrm{N}$-free nutrient solution [60].

\section{Inoculum preparation and plant inoculation}

The B. japonicum strain used for inoculation was CPAC 15 (=SEMIA 5079), which has been used in commercial inoculants in Brazil, since 1992, for its outstanding symbiotic efficiency and competitiveness [4,5]. The bacterium was grown until the exponential phase of growth in 
yeast-mannitol broth (YMB) [59]. The cells were centrifuged and washed with saline solution $(\mathrm{NaCl}$ $0.85 \%)$. Aliquots of washed cell suspension were counted in YMB medium, indicating a concentration of $2.27 \times$ $10^{7}$ cells $\mathrm{mL}^{-1}$.

The experiment had a fully randomized design with three replicates, each consisting of 20 plants per treatment. Treatments consisted of: soybean roots inoculated with strain CPAC 15 and non-inoculated soybean. For the inoculated treatment, $1 \mathrm{~mL}$ of the inoculum was applied at the base of each radicle. The plants were grown under greenhouse condition with a 12-h day/night period and mean temperature of $25-28^{\circ} \mathrm{C} / 15-18^{\circ} \mathrm{C}$ (day/ night) for ten days. Subsequently, the roots were separated from shoots, immediately frozen in liquid nitrogen and stored at $-80^{\circ} \mathrm{C}$.

\section{RNA extraction and isolation of mRNA}

Total RNA was isolated from the roots of each treatment using Trizol (Invitrogen, Carlsbad, CA, USA), according to the manufacturer's instructions. After extraction, total RNA was analyzed for quality using the Thermo Scientific NanoDrop ND-1000 spectrophotometer (NanoDrop Technologies, Wilmington, DE, USA). The mRNA was obtained from $2 \mu \mathrm{g}$ of total RNA using the FastTrack MAG mRNA Isolation Kit (Invitrogen), according to the manufacturer's specifications.

\section{Construction of the suppressive subtractive hybridization (SSH) CDNA library}

This study is a component of a consortium named Genosoja (Brazilian Soybean Genome Consortium). Before the development of all experiments of the Genosoja project, the techniques of RNA extraction, SSH, RNAseq and qPCR were validated in several laboratories, and a standard protocol was applied, including the bioinformatics analyses. The experimental validations were published in a special edition of the Journal "Genetics and Molecular Biology" (v.35, n.1, 2012, http:// www.scielo.br/scielo.php?script=sci_issuetoc\&pid=1415-47572 $0120002 \& \operatorname{lng}=e n \& n r m=i s o)$. A procedure included in the validation was the comparison of SSH and superSAGE strategies, and resulted in congruent results. Due to the high costs we have decided to follow the SSH strategy.

The SSH library was constructed using a PCR-Select cDNA Subtration Kit (Clontech Laboratories Inc, Mountain View, CA, USA), according to the manufacturer's instructions. A cDNA library was built, containing clones from the subtraction of inoculated plants versus non-inoculated plants. This subtractive hybridization was performed using sample cDNAs (tester) from inoculated plants, which was subtracted with cDNAs (driver) from non-inoculated plants. This kind of hybridization is called forward subtraction, to identify the induced genes (up-regulated).

\section{Sequencing and bioinformatics}

The pool of cDNA resulting from the subtractive library was transferred directly to the sequencing reaction with the Genome Analyzer GAII technology Illumina, carried out by Fasteris S.A., in Switzerland.

The reads from sequencing were aligned against the GENOSOJA database (http://www.lge.ibi.unicamp.br/ soybean) [61]. The generated sequences were assembled and preliminarily analyzed at the LGE (Laboratory of Genomic and Expression at UNICAMP, Campinas, São Paulo, Brazil). First, the reads from sequencing were aligned in the reference genome of soybean (Phytozome database) [42] using SOAP software [62], allowing a maximum of two mismatches.

In addition, a level of inference of gene expression by reads per kilobase of exon per million mapped reads (RPKM) was assigned, making it possible to infer the expression level of genes in the subtractive library [63].

AutoFACT software [64] was used for automatic annotation of the sequences, through several BLASTx searches (e-value cutoff of 1e-5) against protein databases including NR (non-redundant from NCBI), Swissprot [65] and KEGG [66]. Subsequently, the transcripts were subjected to functional categorization, which was performed using the Gene Ontology database (http://www.geneontology.org), with Blast2GO [13], enabling clustering of genes according to the biological processes ontology (level 2) and molecular function (level 3). The most relevant metabolic pathways (based on the KEGG database) were also identified.

\section{SSH validation by real-time $\mathrm{QPCR}$ analysis}

Quantitative real-time PCR experiments were performed to validate the expression of two genes, whose RPKM values were relatively low, in order to compare other genes in the library. Therefore, a new plant-inoculation experiment was performed, under the conditions previously described. After extraction of total RNA, the samples were treated with deoxyribonuclease I, amplification grade (Invitrogen), according to the manufacturer's instructions. The cDNA synthesis was carried out using a SuperScript III First-Strand Synthesis System for RTPCR (Invitrogen), according to the manufacturer's instructions.

Primers were designed using PrimerExpress 3.0 (Applied Biosystems, Foster City, CA, USA), and the sequences are available on Additional file 1: Table S3, along with the sequences of the primers for the reference genes for $\beta$-actin [67] and F-box [68], used as endogenous controls.

For the RT-PCR reactions, Platinum SYBR Green qPCR SuperMix-UDG (Invitrogen) was used. Each sample was run in triplicate along with the corresponding non-template controls containing water instead of 
cDNA. Amplification reactions were performed using a 7300 Real-Time PCR System thermal cycler (Applied Biosystems). The amplification cycles were as follows: $50^{\circ} \mathrm{C}$ for $2 \mathrm{~min}, 95^{\circ} \mathrm{C}$ for $10 \mathrm{~min}, 40$ cycles at $95^{\circ} \mathrm{C}$ for $15 \mathrm{~s}$, and $60^{\circ} \mathrm{C}$ for $1 \mathrm{~min}$. For each sample, a threshold cycle $(\mathrm{Ct})$ value was calculated based on the amplification curves by selecting the optimal $\Delta \mathrm{Rn}$ (emission of reporter dye over starting background fluorescence) in the exponential part of the amplification plot. The specificity of the amplified products was evaluated by dissociation-curve analyses. The relative linear amount of target molecules relative to the calibrator was calculated according to Pfaffl [69], with significant differences determined with the REST 2009 software $(\mathrm{p}<0.05)$ (Relative Expression Software Tool [70]).

\section{Proteomics analysis}

Whole-cell proteins of soybean roots were extracted, from both the inoculated and non-inoculated treatments, following the simplified method described by Rodrigues et al. [71]. IPG strips (pH 4-7, $13 \mathrm{~cm}$, GE Healthcare, Uppsala, Sweden) were rehydrated overnight with aliquots of $350 \mu \mathrm{g}$ of solubilized proteins. Next, the strips were submitted to isoelectric focalization and SDS-PAGE as described by Batista and Hungria [72]. Gels were stained overnight with Comassie Brilliant Blue (CBB) R-350 (GE Healthcare), destained in a solution of $40 \%$ ethanol and 10\% acetic acid and scanned (ImageScanner LabScan v. 5.0).

Spots were strictly identified in the high-resolution digitalized gel images and analyzed by Image Master 2D Platinum v 5.0 software (GE Healthcare). Ratios of mean normalized spot volumes were calculated. All selected spots were manually confirmed and statistically evaluated $(\mathrm{p}<0.05)$ upon Student's $\mathbf{t}$-test, using XLSTAT (Addinsoft, France, add-in to Microsoft Excel).

Spots which showed a significantly higher volume in the inoculated condition were excised and processed as described before [72], with trypsin (Gold, mass spectrometry grade, Promega, Madison, WI) at $37^{\circ} \mathrm{C}$ overnight. Tryptic peptides $(0.5 \mu \mathrm{L})$ were mixed with saturated solution of HCCA ( $\alpha$-cyano-4-hydroxy-cinamic acid) in 50\% acetonitrile, $0.1 \%$ TFA (trifluoroacetic acid). The mixture was spotted onto a MALDI sample plate and allowed to crystallize at room temperature. The same procedure was used for the standard peptide calibration mix (Bruker Daltonics).

For mass spectra acquisition, a MALDI-TOF-MS Autoflex spectrometer (Bruker Daltonics) was operated manually in the LIFT mode for MALDI-TOF/TOF, using the FlexControl 3.0 (Bruker Daltonics) software.

PMFs and MS/MS ions generated were searched against the public database NCBInr (National Center for Biotechnology Information non-redundant)/Viridiplantae, using the Mascot software v. 2.3 (Matrix Science). For protein searches, monoisotopic masses were used, considering a peptide tolerance of $150 \mathrm{ppm}$ and allowance of one missed cleavage. When MS/MS was carried out, a tolerance of 0.3 Da was acceptable. Carbamidomethylation of cysteine and oxidation of methionine were considered fixed and variable modifications, respectively.

Identifications were only validated when the Mowse (molecular weight search) score was significant, above the recommended cutoff score. The spectrometry datasets are available at PRIDE (http://ebi.ac.uk/pride/) with the experiment accession number 14846 (Username: review03737, Password: $\left.+6 \mathrm{Nx}+\mathrm{E}^{\wedge} \mathrm{Y}\right)$.

\section{Additional files}

Additional file 1: Table S1. Real- time PCR result of differential expression of two target genes from soybean roots inoculated (sample) and mock-inoculated (calibrator) using $2^{-\Delta \Delta C t}$ method. Table S2. Genes which encode enzymes present in the glycolytic pathway (A) and in the Krebs cycle (B) found in the subtractive library of soybean cv. Conquista when inoculated with B. japonicum strain CPAC 15. Table S3- Sequences of the primers used in the RT-qPCR and sizes of the PCR products obtained.

Additional file 2: Figure S1. Glycolysis pathway during nodulation of soybean cultivar Conquista at 10 days after inoculation with B. japonicum CPAC 15 (ID Kegg map00010). Figure S2. Krebs cycle of soybean cultivar Conquista at 10 days after inoculation with B. japonicum CPAC 15 (ID Kegg map00020). Figure S3. Glutathione metabolism - the antioxidant defense system present in the nodulation (ID Kegg- map00480). Figure S4. Carbohydrate metabolism involved in the reorganization of the plant cell wall during organogenesis of the nodule (ID Kegg-map00500). Figure S5. Spots of whole-cell protein extracts of soybean roots inoculated (left images) and non-inoculated (right images) with $B$. japonicum. Proteins identified corresponds to sucrose synthase (1) and putative glutathione-S-transferase (2).

\section{Competing interest}

The authors declare that they have no scientific or financial competing interests.

\section{Author-recommended internet resource}

Site for the data http://www.lge.ibi.unicamp.br/soybean. In Browse, subtractive libraries.

\section{Authors' contributions}

Conceived and designed the experiments: MH, FCM-G. Performed the experiments: GABdC, JSdSB. Analyzed the data: All authors. Contributed reagents/materials/analysis tools: $\mathrm{MH}$ Wrote the paper: All authors. All authors read and approved the final manuscript.

\section{Acknowledgments}

To Dr. Elisete R.P. Rodrigues and Aline Schiavon for helping in the conduction of the experiments. To Marcelo F. Carazzolle and Gonçalo A.G. Pereira for helping in the bioinformatics analysis and Dr. Allan R.J. Eaglesham for suggstions on the manuscript. G.A.B. Carvalho acknowledges an MSc fellowship from CAPES (Coordenação de Aperfeiçoamento do Pessoal de Nível Superior), J.S.S. Batista a postdoc fellowship from CNPq (National Council for Scientific and Technological Development) and M Hungria a research fellowship from CNPq (300547/2010-2). Project funded by CNPq projects Genosoja, MAPA (577933/2008-6) and Repensa (562008/2010-1). Approved for publication by the Editorial Board of Embrapa Soja as manuscript 10/2012. 


\section{Author details}

${ }^{1}$ Empresa Brasileira de Pesquisa Agropecuária, CNPSo, PO Box 231, Londrina, Paraná 86001-970, Brazil. '2Department of Biochemistry and Biotechnology, Universidade Estadual de Londrina, PO Box 6001, Londrina, Paraná 86051-990, Brazil. 'Laboratório de Genômica e Expressão, Institute of Biology, Universidade Estadual de Campinas, Rua Monteiro Lobato, 255, Campinas, São Paulo 13083-862, Brazil.

Received: 14 January 2013 Accepted: 28 February 2013 Published: 6 March 2013

\section{References}

1. Graham PH, Vance CP: Legumes: importance and constraints to greater use. Plant Physiol 2003, 131(3):872-877.

2. Brechenmacher L, Kim MY, Benitez M, Li M, Joshi T, Calla B, Lee MP, Libault M, Vodkin LO, Xu D, Lee SH, Clough SJ, Stacey G: Transcription profiling of soybean nodulation by Bradyrhizobium japonicum. Mol Plant Microbe Interact 2008, 21(5):631-645.

3. Oldroyd GE, Murray JD, Poole PS, Downie JA: The rules of engagement in the legume- rhizobial symbiosis. Annu Rev Genet 2011, 45:119-144.

4. Hungria M, Campo RJ, Mendes IC, Graham PH: Contribution of biological nitrogen fixation to the $\mathrm{N}$ nutrition of grain crops in the tropics: the success of soybean (Glycine max L. Merr.) in South America. In Nitrogen nutrition and sustainable plant productivity. Edited by Singh RP, Shankar N, Jaiwal PK. Houston, Texas: Studium Press, LLC; 2006:43-93.

5. Hungria M, Franchini JC, Campo RJ, Crispino CC, Moraes JZ, Sibaldelli RNR, Mendes IC, Arihara J: Nitrogen nutrition of soybean in brazil: contributions of biological $\mathrm{N}_{2}$ fixation and $\mathrm{N}$ fertilizer to grain yield. Can J Plant Sci 2006, 86(4):927-939.

6. Stougaard J: Regulators and regulation of legumes root nodule development. Plant Physiol 2000, 124(2):531-540.

7. Ferguson BJ, Mathesius U: Signaling interactions during nodule development. J Plant Growth Regul 2003, 22:47-72.

8. Limpens E, Bisseling T: Signaling in symbiosis. Curr Opin Plant Biol 2003, 6(4):343-350.

9. Stacey G, Libault M, Brechenmacher L, Wan J, May GD: Genetics and functional genomics of legume nodulation. Curr Opin Plant Biol 2006, 9(2):110-121.

10. Ferguson BJ, Indrasumunar A, Hayashi S, Lin MH, Lin YH, Reid DE, Gresshoff PM: Molecular analysis of legume nodule development and autoregulation. J Integr Plant Biol 2010, 52(1):61-76.

11. Libault M, Farmer A, Brechenmacher L, Drnevich J, Langley RJ, Bilgin DD, Radwan O, Neece DJ, Clough SJ, May GD, Stacey G: Complete transcriptome of the soybean root hair cell, a single-cell model, and its alteration in response to Bradyrhizobium japonicum infection. Plant Physiol 2010, 152(2):541-552.

12. Diatchenko L, Lau YF, Campbell AP, Chenchik A, Mogadam F, Huang B, Lukyanov S, Lukyanov K, Gurskaya N, Sverdlov ED, Siebert PD: Suppression subtractive hybridization: a method for generating differentially regulated or tissue-specific cDNA probes and libraries. PNAS 1996, 93(12):6025-6030.

13. Conesa A, Götz S: Blast2GO: a comprehensive suite for functional analysis in plant genomics. Int J Plant Genomics 2008, 2008:619832

14. El Yahyaoui F, Küster H, Ben Amor B, Hohnjec N, Pühler A, Becker A, Gouzy J, Vernié T, Gough C, Niebel A, Godiard L, Gamas P: Expression profiling in Medicago truncatula identifies more than 750 genes differentially expressed during nodulation, including many potential regulators of the symbiotic program. Plant Physiol 2004, 136(2):3159-3176.

15. Lohar DP, Sharopova N, Endre G, Peñuela S, Samac D, Town C, Silverstein KA, Vandenbosch KA: Transcript analysis of early nodulation events in Medicago truncatula. Plant Physiol 2006, 140(1):221-234.

16. Starker CG, Parra-Colmenares AL, Smith L, Mitra RM, Long SR: Nitrogen fixation mutants of Medicago truncatula fail to support plant and bacterial symbiotic gene expression. Plant Physiol 2006, 140(2):671-680.

17. Kouchi H, Shimomura K, Hata S, Hirota A, Wu GJ, Kumagai H, Tajima S, Suganuma N, Suzuki A, Aoki T, Hayashi M, Yokoyama T, Ohyama T, Asamizu E, Kuwata C, Shibata D, Tabata S: Large-scale analysis of gene expression profiles during early stages of root nodule formation in a model legume, Lotus japonicus. DNA Res 2004, 11(4):263-274.

18. Asamizu E, Nakamura Y, Sato S, Tabata S: Comparison of the transcript profiles from the root and the nodulating root of the model legume Lotus japonicus by serial analysis of gene expression. Mol Plant Microbe Interact 2005, 18(5):487-498.
19. Delauney AJ, Cheon Cl, Snyder PJ, Verma DP: A nodule-specific sequence encoding a methionine-rich polypeptide, nodulin-21. Plant Mol Biol 1990 14(3):449-451

20. Sandal NN, Bojsen K, Marcker KA: A small family of nodule specific genes form soybean. Nucl Acids Res 1987, 15(4):1507-1519.

21. Miao GH, Verma DP: Soybean nodulin-26 gene encoding a channel protein is expressed only in the infected cells of nodules and is regulated differently in roots of homologous and heterologous plants. Plant Cell 1993, 5(7):781-794.

22. Kouchi H, Hata S: Isolation and characterization of novel nodulin cDNAs representing genes expressed at early stages of soybean nodule development. Mol Gen Genet 1993, 238(1-2):106-119.

23. Lee H, Hur CG, Oh CJ, Kim HB, Pakr SY, An CS: Analysis of the root noduleenhanced transcriptome in soybean. Mol Cells 2004 18(1):53-62.

24. Desbrosses GJ, Stougaard J: Root nodulation: a paradigm for how plantmicrobe symbiosis influences host developmental pathways. Cell Host Microbe 2011, 10(4):348-358.

25. Hayashi S, Reid DE, Lorenc MT, Stiller J, Edwards D, Gresshoff PM, Ferguson BJ: Transient Nod factor-dependent gene expression in the nodulationcompetent zone of soybean (Glycine max [L.] Merr.) roots. Plant Biotechnol J 2012, 10(8):995-1010.

26. Neves MCP, Hungria M: The physiology of nitrogen fixation in tropical grain legumes. Crit Rev Plant Sci 1987, 6(3):267-321.

27. Colebatch G, Desbrosses G, Ott T, Krusell L, Montanari O, Kloska S, Kopka J, Udvardi MK: Global changes in transcription orchestrate metabolic differentiation during symbiotic nitrogen fixation in Lotus japonicus. Plant J 2004, 39(4):487-512.

28. Colebatch G, Kloska S, Trevaskis B, Freund S, Altmann T, Udvardi MK: Nove aspects of symbiotic nitrogen fixation uncovered by transcript profiling with cDNA arrays. Mol Plant Microbe Interact 2002, 15(5):411-420.

29. Vance $C P$, Gantt JS: Control in nitrogen and carbon metabolism in rootnodules. Physiol Plant 1992, 85(2):266-274

30. Curioni PMG, Hartwig UA, Nösberger J, Schuller KA: Glycolytic flux is adjusted to nitrogenase activity in nodules of detopped and argontreated alfalfa plants. Plant Physiol 1999, 119(2):445-453.

31. Frendo P, Harrison J, Norman C, Jiménez MJH, Van de Sype G, Gilabert A Puppo A: Glutathione and homoglutathione play a critical role in the nodulation process of Medicago truncatula. Mol Plant Microbe Interact 2005, 18(3):254-259.

32. Chang C, Damiani I, Puppo A, Frendo P: Redox changes during the legume-Rhizobium symbiosis. Mol Plant 2009, 2(3):370-377.

33. Santos R, Herouart D, Sigaud S, Touati D, Puppo A: Oxidative burst in alfalfa-Sinorhizobium meliloti symbiotic interaction. Mol Plant Microbe Interact 2001, 14(1):86-89.

34. Cárdenas L, Martínez A, Sánchez F, Quinto C: Fast, transient and specific intracellular ROS changes in living root hair cells responding to Nod factors (NFs). Plant J 2008, 56(5):802-813.

35. Pucciariello C, Innocenti G, Van de Velde W, Lambert A, Hopkins J, Clément M, Ponchet M, Pauly N, Goormachtig S, Holsters M, Puppo A, Frendo P: (Homo)glutathione depletion modulates host gene expression during the symbiotic interaction between Medicago truncatula and Sinorhizobium meliloti. Plant Physiol 2009, 151(3):1186-1196.

36. Ding Y, Oldroyd GE: Positioning the nodule, the hormone dictum. Plant Signal Behav 2009, 4(2):89-93.

37. Searle IR, Men AE, Laniya TS, Buzas DM, Iturbe-Ormaetxe I, Carroll BJ, Gresshoff PM: Long- distance signaling in nodulation directed by a CLAVATA1-like receptor kinase. Science 2003, 299(5603):109-112.

38. Zhu H, Riely BK, Burns NJ, Ané JM: Tracing nonlegume orthologs of legume genes required for nodulation and arbuscular mycorrhizal symbioses. Genetics 2006, 172(4):2491-2499.

39. Stracke S, Kistner C, Yoshida S, Mulder L, Sato S, Kaneko T, Tabata S, Sandal N, Stougaard J, Szczyglowski K, Parniske M: A plant receptor-like kinase required for both bacterial and fungal symbiosis. Nature 2002, 417(6892):959-962.

40. Capoen W, Goormachtig S, Rycke RD, Schroeyers K, Holsters M: SrSymRK, a plant receptor essential for symbiosome formation. PNAS 2005, 102(29):10369-10374.

41. Oldroyd GE, Downie JA: Calcium, kinases and nodulation signalling in legumes. Nat Rev Mol Cell Biol 2004, 5(7):566-576.

42. Schmutz J, Cannon SB, Schlueter J, Ma J, Mitros T, Nelson W, Hyten DL, Song Q, Thelen JJ, Cheng J, Xu D, Hellsten U, May GD, Yu Y, Sakurai T, 
Umezawa T, Bhattacharyya MK, Sandhu D, Valliyodan B, Lindquist E, Peto M, Grant D, Shu S, Goodstein D, Barry K, Futrell-Griggs M, Abernathy B, Du J, Tian Z, Zhu L, et al: Genome sequence of the palaeopolyploid soybean. Nature 2010, 463:178-183.

43. Christensen A, Svensson K, Persson S, Jung J, Michalak M, Widell S, Sommarin M: Functional characterization of Arabidopsis calreticulin1a: a key alleviator of endoplasmic reticulum stress. Plant Cell Physiol 2008, 49(6):912-924.

44. Jia $X Y$, He LH, Jing RL, Lia RZ: Calreticulin: conserved protein and diverse functions in plants. Physiol Plant 2009, 136(2):127-138.

45. Gupta D, Tuteja N: Chaperones and foldases in endoplasmic reticulum stress signaling in plants. Plant Signal Behav 2011, 6(2):232-236.

46. Crouzet J, Trombik T, Fraysse AS, Boutry M: Organization and function of the plant pleiotropic drug resistance $A B C$ transporter family. FEBS Lett 2006, 580(4):1123-1130.

47. Sugiyama A, Shitan N, Yazaki K: Signaling from soybean roots to rhizobium. Plant Signal Behav 2008, 3(1):38-40

48. Kasprzewska A: Plant chitinases: regulation and function. Cell Mol Biol Let 2003, 8(3):809-824

49. Santos $P$, Fortunato A, Ribeiro A, Pawlowski K: Chitinases in root nodules. Plant Biotechnol 2008, 25:299-307.

50. Xie ZP, Staehelin C, Wiemken A, Broughton WJ, Müller J, Boller T: Symbiosis-stimulated chitinase isoenzymes of soybean (Glycine max (L.) Merr.). J Exp Bot 1999, 50(332):327-333.

51. Benedito VA, Li H, Dai X, Wandrey M, He J, Kaundal R, Torres-Jerez I, Gomez SK, Harrison MJ, Tang Y, Zhao PX, Udvardi MK: Genomic inventory and transcriptional analysis of Medicago truncatula transporters. Plant Physio 2010, 152(3):1716-1730.

52. Kjellbom P, Larsson C, Johansson I, Karlsson M, Johanson U: Aquaporins and water homeostasis in plants. Trends Plant Sci 1999, 4(8):308-314.

53. Johansson I, Karlsson M, Johanson U, Larsson C, Kjellbom P: The role of aquaporins in cellular and whole plant water balance. Biochim Biophys Acta 2000, 1465(1-2):324-334.

54. Uehlein N, Fileschi K, Eckert M, Bienert GP, Bertl A, Kaldenhoff R: Arbuscular mycorrhizal symbiosis and plant aquaporin expression. Phytochemistry 2007, 68(1):122-129.

55. Benedito VA, Dai X, He J, Zhao PX, Udvardi MK: Functional genomics of plant transporters in legume nodules. Funct Plant Biol 2006, 33(8):731-736.

56. Kaewsuralikhit S, Yokoyama T, Kouchi H, Arima Y: Comprehensive analysis of plant gene expression in soybean root nodules at different growth stages. Soil Sci Plant Nutrit 2006, 51(4):535-547.

57. Lievens S, Goormachtig S, Herman S, Holsters M: Patterns of pectin methylesterase transcripts in developing stem nodules of Sesbania rostrata. Mol Plant Microbe Interact 2002, 15(2):164-168. 2002.

58. Koch K: Sucrose metabolism: regulatory mechanisms and pivotal roles in sugar sensing and plant development. Curr Opin Plant Biol 2004 2004, 7(3):235-246.

59. Vincent JM: A manual for the practical study of root nodule bacteria. Oxford: Science Blackwell publishing; 1970:164.

60. Broughton WJ, Dilworth MJ: Methods in legume-rhizobium technology: plant nutrient solutions. In Handbook for rhizobia. Edited by Somasegaran P, Hoben HJ. Hawaii: NifTAL Project and University of Hawaii; 1970:245-249.

61. Nascimento LC, Costa GGL, Binneck E, Pereira GAG, Carazzolle MF: A webbased bioinformatics interface applied to the GENOSOJA Project: Databases and pipelines. Genet Mol Biol 2012, 35(1):203-211.

62. Li R, Li Y, Kristiansen K, Wang J: SOAP: short oligonucleotide alignment program. Bioinformatics 2008, 24(5):713-714.

63. Mortazavi A, Williams BA, McCue K, Schaeffer L, Wold B: Mapping and quantifying mammalian transcriptomes by RNA-Seq. Nat Methods 2008, 5(7):621-628.

64. Koski LB, Gray MW, Lang BF, Burger G: AutoFACT: an automatic functional annotation and classification tool. BMC Bioinforma 2005, 6:151.

65. Suzek BE, Huang H, McGarvey P, Mazumder R, Wu CH: UniRef: comprehensive and non-redundant UniProt reference clusters. Bioinformatics 2007, 23(10):1282-1288.

66. Kanehisa M, Goto S: KEGG: Kyoto encyclopedia of genes and genomes. Nucl Acids Res 2000, 28(1):27-30.

67. Stolf-Moreira R, Lemos EGM, Abdelnoor RV, Beneventi MA, Rolla AAP, Pereira SS, Oliveira MCN, Nepomuceno AL, Marcelino-Guimarães FC: Identification of reference genes for expression analysis by real-time quantitative PCR in drought-stressed soybean. Pesq Agrop Brasil 2011, 46(1):58-65.
68. Libault M, Thibivilliers S, Bilgin DD, Radwan O, Benitez M, Clough SJ, Stacey G: Identification of four soybean reference genes for gene expression normalization. Plant Genome 2008, 1:444-454.

69. Pfaffl MW: A new mathematical model for relative quantification in realtime RT-PCR. Nucl Acids Res 2001, 29(9):e45.

70. Pfaffl MW, Horgan GW, Dempfle L: Relative expression software tool (REST) for group- wise comparison and statistical analysis of relative expression results in real-time PCR. Nucl Acids Res 2002, 30(9):e36.

71. Rodrigues EP, Torres AR, Batista JSS, Huergo L, Hungria M: A simple, economical and reproducible protein extraction protocol for proteomics studies of soybean roots. Genet Mol Biol 2012, 35(1):348-352.

72. Batista JSS, Hungria M: Proteomics reveals differential expression of proteins related to a variety of metabolic pathways by genistein-induced Bradyrhizobium japonicum strains. J Proteomics 2012, 75(4):1211-1219.

\section{doi:10.1186/1471-2164-14-153}

Cite this article as: Barros de Carvalho et al.: Transcriptional analysis of genes involved in nodulation in soybean roots inoculated with Bradyrhizobium japonicum strain CPAC 15. BMC Genomics 2013 14:153.

\section{Submit your next manuscript to BioMed Central and take full advantage of:}

- Convenient online submission

- Thorough peer review

- No space constraints or color figure charges

- Immediate publication on acceptance

- Inclusion in PubMed, CAS, Scopus and Google Scholar

- Research which is freely available for redistribution 